\title{
Peertechz
}

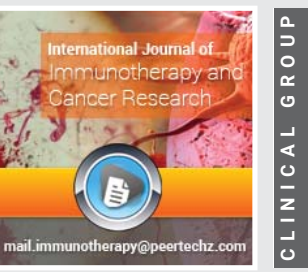

\section{Invasive squamous cell carcinoma of the conjunctiva}

\author{
Sonda Kammoun, Mona Rekik*, Saloua Ben Amor and \\ Jamel Feki
}

Department of Ophthalmology, Habib Bourguiba Hospital 3029 Sfax, Tunisia

Received: 11 September, 2020

Accepted: 07 October, 2020

Published: 08 October, 2020

*Corresponding author: Mona Rekik, Department of Ophthalmology, Habib Bourguiba Hospital 3029 Sfax, Tunisia, Tel: +00 216 24300099;

E-mail: rekikmona@yahoo.fr

Keywords: Squamous cell carcinoma of the conjunctiva; Invasive; Extension; Biopsy; Exenteration

https://www. peertechz.com

\section{Check for updates}

\section{Abstract \\ Introduction: Squamous cell carcinoma of the conjunctiva is generally a low-grade tumor. Invasive squamous cell carcinoma, however, is uncommon, and intraocular extension has rarely been reported. We report a case of invasive squamous cell carcinoma of the conjunctiva with intra-ocular involvement in 94 year-old man. \\ Methods: A case report. \\ Results: A 94-year-old male patient presented with a rapidly growing exophytic mass involving the right eyeball for 2 months. The biopsy performed a well differentiated squamous cell carcinoma of the conjunctiva. \\ The extension assessment showed local bone extension. The patient underwent exenteration with good postoperative consequences. \\ Conclusion: This disease has a variable appearance. Late presentation with large orbital tumours are not uncommon. Early diagnosis is crucial to improve the visual prognosis.}

\section{Introduction}

Squamous cell carcinoma is the most common epithelial malignancy of the conjunctiva [1]. The tumor primarily affects middle-aged to elderly male patients [1]. Sun injury, viral infections, and immunocompromised states are known etiological factors. The limbal epithelial cells appear to be the progenitors of this disease [2].

It is generally a low-grade tumor. Invasive squamous cell carcinoma, however, is uncommon, and intraocular extension has rarely been reported [3].

Here, we report an unusual case of invasive squamous cell carcinoma of the conjunctiva with intra-ocular involvement.

\section{Case report}

A 94 year-old man presented with a rapidly growing mass in the right eye for 2 months. The ophthalmological examination of the right eye showed an exophytic lesion protruding through the lids and involving the eyeball (Figure
1). The left eye was entirely normal. The magnetic resonance imaging of the orbits showed a large heterogeneous anterior lesion, measuring $2.8 * 3.3 \mathrm{~cm}$, adjacent to the inner canthus of the right orbit and involving the lacrimal gland (Figure 2). A small excision biopsy was taken from the exophytic lesion and performed a well differentiated squamous cell carcinoma of the conjunctiva. The extension assessment showed local bone

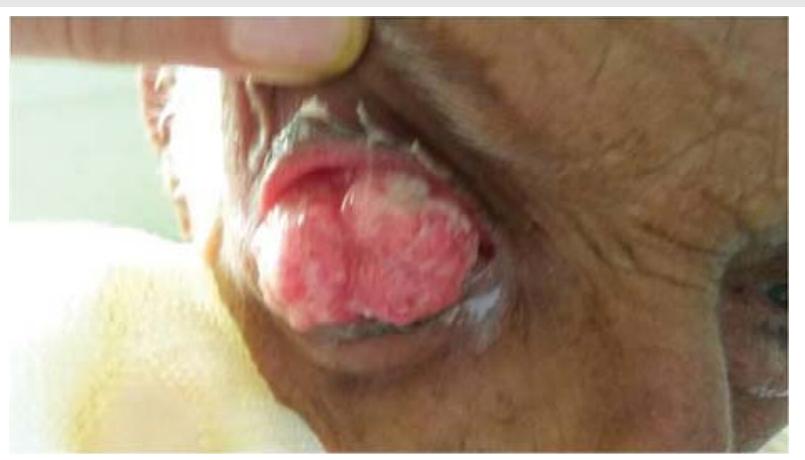

Figure 1: An exophytic mass protruding through the lids and involving the right eyeball.

Citation: Kammoun S, Rekik M, Amor SB, Feki J (2020) Invasive squamous cell carcinoma of the conjunctiva. Int J Immunother Cancer Res 6(1): 022-024. 


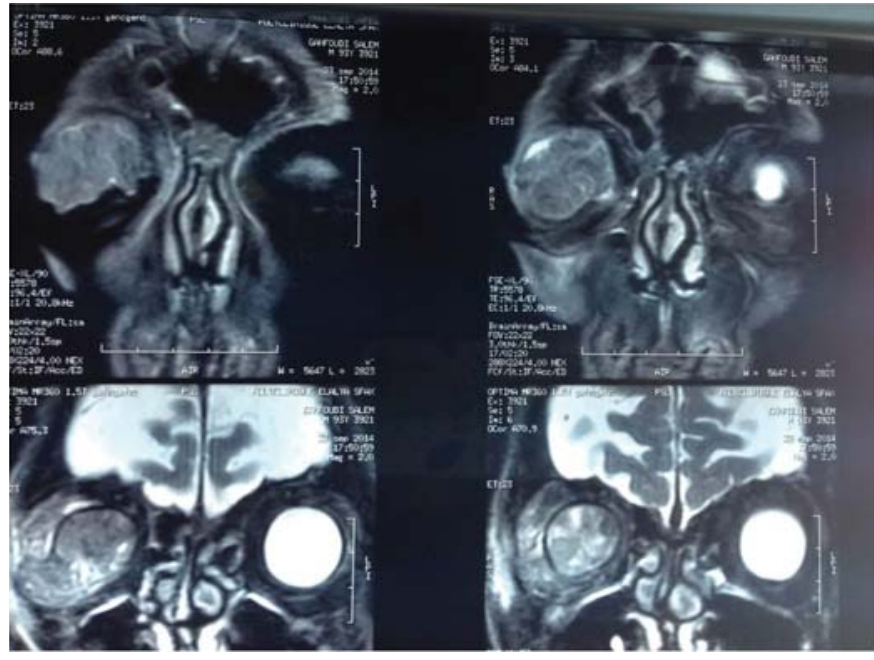

Figure 2: The magnetic resonance imaging shows large heterogeneous anterior lesion, adjacent to the inner canthus of the right orbit and involving the lacrimal gland.

extension to the inner wall of the right orbit and the lower part of the frontal sinus. Subsequently, exenteration was done. The patient was followed up for 1 year, and during this period, no recurrence was noted. After that, we lost the patient for followup.

\section{Discussion}

Conjunctival squamous cell carcinomas (SCCC) are rare neoplasms affecting commonly aged male patients $[4,5]$.

There are several predisposing factors like exposure to ultraviolet-B radiation, HIV/AIDS and other types of immunodeficiencies such as medical immunosuppression, xeroderma pigmentosum and atopic diseases. The aetiological role of human papilloma virus (HPV) has been determined, due to the well-documented role in other lesions of the eye, such as conjunctival papilloma and lacrimal sac neoplasia, and squamous cell carcinomas of the skin [6].

Although it is the most frequently seen malignant neoplasm of the conjunctival epithelium, the literature suggests that it normally behaves in a nonaggressive fashion [5].

The manifestations of SCCC are highly variable and depend on the stage of the tumor. They are sometimes misleading, assuming the appearance of a benign lesion neglected by the patient, resulting in diagnostic and therapeutic delay.

Majority of the patients present with a nodular lesion in the limbus or other parts of the conjunctiva [5]. Most lesions occur in the interpalpebral fissure, especially on the nasal side. Rarely, late presentation with large orbital tumors and diffuse involvement is seen [2]. Invasion deep in the stroma, in the orbit, or in the eye can result in vision loss [7].

Large exophytic tumor, as we saw in our case, is a rare presentation. To our knowledge, large orbital tumor involving the eyeball as the presenting sign of squamous cell carcinoma has not been previously reported.
The mean delay of diagnosis is usually 7 months after onset [1]. Our patient sought medical attention at 2 months after tumor development, but the mass was aggressive enough to cause blindness.

We postulated that the short interval from the tumor's first appearance to the time the patient seeks medical attention may be explained by rapid growth from strong sunlight exposure in this environment or because of ignorance of the patient at the first appearance of the tumor.

Histopathology is the gold standard for diagnosis [8]. The treatment of conjunctival SCC is wide excision. Enucleation is advised when cornea or sclera has been invaded, and exenteration is recommended in cases of invasion of anterior orbit [9], like in the case of our patient. Exenteration is a radical technique that involves removing all the orbital contents including the periosteum [8].

Metastasis occurs rarely, and commonly parotid or submandibular glands are involved. Even with metastasis, the chance of survival is good $[5,10]$.

\section{Conclusion}

Invasive malignancy of conjunctiva is a rare neoplasm. However, it should be suspected in all aged patients with a conjunctival lesion, particularly with the rapid rate of growth. Late presentation with large orbital tumours are uncommon. The possibility of an intraocular diffusion of this tumour must be always evaluated, and the need for prompt surgical treatment considered. Proper management is crucial to improve the visual prognosis.

We are presenting this rare case report to promote awareness about this uncommon malignancy which will help in accurate management in future.

\section{Declaration of patient consent}

The authors certify that they have obtained all appropriate patient consent forms. In the form the patient has given his consent for his images and other clinical information to be reported in the journal.

\section{References}

1. Tulvatana W, Tirakunwichcha S (2006) Multifocal Squamous Cell Carcinoma of the Conjunctiva With Intraocular Penetration in a Patient With AIDS. Cornea 25: 745-747. Link: https://bit.ly/3nssrqb

2. Gichuhi S, Sagoo MS (2016) Squamous cell carcinoma of the conjunctiva Community Eye Health 29: 52-53. Link: https://bit.ly/2GpJU29

3. De Felice GP, Viale G, Caroli R (1990) Deeply invasive squamous cell carcinoma of the conjunctiva: case report. Int Ophthalmol 14: 241-244. Link: https://bit.ly/34u0khW

4. Ramberg I, Heegaard S, Prause JU, Christian Sjo N, et al. (2015) Squamous cell dysplasia and carcinoma of the conjunctiva. A nationwide, retrospective epidemiological study of Danish patients. Acta Ophthalmol 93: 663-666. Link: https://bit.ly/3ntwEdw

5. Bagdi S, Phukan JP, Sinha A, Chakraborty T (2018) Invasive squamous cel carcinoma of the conjunctiva: Report of a case diagnosed by imprint cytology 
and histopathology. Clinical Cancer Investigation Journal 7: 162-164. Link: https://bit.ly/2GAANLZ

6. Espildora IG, Jans J, Guajardo MP, Veliz MM, Perez JCF, et al. (2016) Squamous cell carcinoma of the conjunctiva with extraocular involvement: case report and literature review. Medwave 16: e6453. Link: https://bit.ly/34wpBYz

7. Hämmerl L, Ferlay J, Borok M, Carrilho C, Parkin D (2019) The burden of squamous cell carcinoma of the conjunctiva in Africa. Cancer Epidemiol 61: 150-153. Link: https://bit.ly/3izD1Z3
8. Acis D, Donnio A, Ayéboua L, Richer R, Guyomarch J, et al. (2008) Carcinome épidermoïde conjonctival. À propos de quatre cas aux Antilles. Journal français d'ophtalmologie 31: 533.e1-533.e5. Link: https://bit.ly/3iGuy6a

9. Seikh K, Shastri M (2002) Pigmented squamous cell carcinoma of conjunctiva - A rare case. NHL J Med Sci 3: 82-84.

10. Sharma AK, Bharadwaj S (2002) Squamous cell carcinoma of the conjunctiva. JK Sci 4: $39-40$
Discover a bigger Impact and Visibility of your article publication with Peertechz Publications

\section{Highlights}

* Signatory publisher of ORCID

* Signatory Publisher of DORA (San Francisco Declaration on Research Assessment)

* Articles archived in worlds' renowned service providers such as Portico, CNKI, AGRIS, TDNet, Base (Bielefeld University Library), CrossRef, Scilit, J-Gate etc.

* Journals indexed in ICMJE, SHERPA/ROMEO, Google Scholar etc.

* OAI-PMH (Open Archives Initiative Protocol for Metadata Harvesting)

* Dedicated Editorial Board for every journal

* Accurate and rapid peer-review process

* Increased citations of published articles through promotions

* Reduced timeline for article publication

Submit your articles and experience a new surge in publication services

(https://www.peertechz.com/submission).

Peertechz journals wishes everlasting success in your every endeavours.

Copyright: ๑ 2020 Kammoun S, et al. This is an open-access article distributed under the terms of the Creative Commons Attribution License, which permits unrestricted use, distribution, and reproduction in any medium, provided the original author and source are credited. 